\title{
Dynamic relationship between landscape and new energy system categories
}

\author{
Elisabetta Ginelli and Gianluca Pozzi ${ }^{*}$ (i)
}

\begin{abstract}
Landscape is an ethics-oriented human action. Even energy systems have an active role in structuring landscape. They must establish with landscape a positive and proactive role and be able to guide it towards a conscious and structured goal. To do this, energy systems should be first identified through a functional and perceptual classification, whose steps include: structuring of the information system; identification of principles and of objective and requirement classes for interpretative classification; benchmarks for the perceptive classification of the energy systems in use; classification method; results. This process attempts to define which cases can be positive for landscape and are recognized by stakeholders as such. This, however, without using ordinary analysis and management systems. These techniques often seem to originate from the assumption that landscape is just an unchanging good to be preserved and that any human action involving it, especially with regards to energy systems, should produce the least possible impact. The starting point intends to be different, as different are also the concept of landscape and the idea of energy systems. The identified interpretive categories, related to the use of the energy system, mean to be proactive and meta-planning, as well as to provide guidelines for defining a project's contours and possible, positive role within landscape and lived space.
\end{abstract}

Keywords: Energy systems, Landscape active-driven design, Perception, Well-informed planning guidelines

\section{Introduction}

\section{Energy systems and landscape: the overcoming} of conservative and technocratic interpretation

According to the European Landscape Convention it is necessary to introduce an extensive and dynamic concept of landscape. It can also be observed that the need to define landscape should be strongly criticized, that landscape should rather be read as something which is never fixed by nature and seen as a subject, that is, all the elements forming part of a pattern to all the possible mutations, with both creative and destructive effects (Zagari 2006).

Landscape is not to be considered as a notion, but rather as a faithful expression of existence; a revealed truth itself, and not a geographical theory or an aesthetic value (Dardel et al. 1986).
It is clear and universally accepted that all $^{1}$ landscapes are defined by men: men take landscapes from the places they dwell in and modify them; thus they become not only aesthetic situations (figurative and strongly connected to appearance), but primarily ethical conditions. Those human actions that create landscape are directed actions, designed towards an aim. Man has shaped landscape forms-both those observed and beyond his control, and those freely created-from nature in its cosmic expression. Theoria ${ }^{2}$ has always transferred an anthropic essence on natural environments (Meschiari 2008).

Landscape is the "result of man's activity on nature" (Venturi Ferriolo 2002, p. 11). In this sense, the notion that landscape was born in Romanticism as an aesthetic vision of nature is therefore to be rejected. It is a

*Correspondence: gianluca.pozzi@polimi.it

Dipartimento di Architettura, Ingegneria delle Costruzioni e Ambiente Costruito, Via Giuseppe Ponzio, 31, 20133 Milan, Italy

\footnotetext{
${ }^{1}$ Even in extreme places, considered natural, it is possible to trace human actions: inorganic wastes and residual gases produced by human activity can be found even in Antarctica or on Everest.

2 Theoria is the contemplation of divine in the world. According to Greek ethos it covers all active life and contemplation, where sacred and landscape found an immanent, undisputed unity.
} 
cross-referring topic, even if considered with different focuses, in all eras of human activity. For the ancients it represented the overall purpose of human life.

In a specific society, interest and taste for landscape painting rise and fall in close association with the interests and tastes that society manifests with a more or less defined imprinting in natural landscape. From a social point of view and perception of landscape, it is interesting to consider the concept of "landscape's law of inertia" (Sereni 1961). Once fixed in determined shapes, landscape tends to perpetuate them, even when those technical, productive and social relations that have influenced its origin no longer exist, waiting for newer and more decisive developments to come over.

One of the few definitions that can certainly be attributed to landscape states that it is an abstraction of man caught between ethics and aesthetics. Mankind creates a landscape (one of many that can be created) contemplating (aesthetic) a portion of the reality in which that landscape is immersed, to which it belongs and where it operates (ethics) in absolute freedom. In these terms, landscape can therefore be considered "a contemplation horizon, a product of freedom, a result of art, the effect of human action" (Venturi Ferriolo 2002, p. 16) or as "nature changed by man throughout history" (Venturi Ferriolo 2002, p. 143).

Thus, it can be assumed that mankind creates landscape with a dual connotation: on one hand, man shapes the places where he lives according to the spirit of his time; and, on the other, he gives the places he observes an aesthetic imprint which distorts and unifies them at the same time. When it comes to energy landscapes, this is even more undeniable.

People have always transformed and shaped the places they lived in for energy purposes (Blaschke et al. 2013): dug the earth to extract coal and oil, cut trees to produce heat, changed the course of rivers to bridle the power of water to produce kinetic energy, built immense waterways (Roman aqueducts and others) to quench and entertain entire cities, built windmills to wrest land from the sea.

The transformation of resources into energy is therefore an aspect of landscape that can be traced through the centuries until the present days, validating the attribute of "energy" landscape (DeWall and Stremke 2014).

An "energy landscape" is usually recognized by the scientific community (Ginelli and Daglio 2014a) as the shape which a molecular entity or the spatial interrelation of molecules and molecular forces can take.

Here, instead, we are giving the term "energy landscape" the same dignity of landscape in a broad sense, acknowledging the strategic role of ESs in modelling and defining landscape, whether it is profoundly anthropic (cities) or para-natural (Ginelli and Daglio 2015).
Within an energy landscape, then, some elements can be identified that stand out compared to others, because they are dimensionally larger, more salient or more meaningful. These landmarks are here considered in perceptual and functional terms (Mainardi Peron and Falchero 1994): perceptual, as they depend on their relationship with the subject-observer and on the cognitive value being assigned to them (Llausas and Nogue 2012); functional because they are important for the subject, who must carry out certain actions in that given context (Matsuoka and Kaplan 2008).

A famous example of a building that has iconically become the landmark of a city is the Guggenheim Museum in Bilbao, which has assumed the same value of the Eiffel Tower in Paris: the building is both a symbol and a reference point for moving through the city. If the Eiffel Tower was meant to be a sign of French technique's provisional value on the occasion of a temporary ${ }^{3}$ event, the Guggenheim was consciously desired to give the world the opportunity to know the capital of the Basque Country, for economic and cultural purposes.

However, a Roman aqueduct is seen as an integral part of the landscape and is reasonably protected as a World Heritage Site, while the perception of the latest energy production systems is quite different (Pasqualetti 2011). But what is the difference between a hydroelectric plant built in the early 900 and any of today's hydropower plants, getting continuously attacked because they irreparably change the land we live in? After all, even the sluices designed by Leonardo da Vinci on the Adda River and on the Navigli canals in Italy have heavily modified the landscape, although they are now protected and a museum has been opened on them (Ecomuseum of Leonardo da Vinci).

From this point of view, it is difficult to apply the established analysis systems for estimating the impact of energy systems (Ginelli and Daglio 2014b), borrowed from environmental assessment regulations. The impact of energy systems can be analysed and managed using several systems and techniques (Jorgensen et al. 2008): multidimensional investigations, multicriteria (Theodor et al. 2013), multivariate investigation (Harris et al. 2014), other complex techniques taken from ecology of the landscape assessments (Paolillo et al. 2013).

All these techniques, however, seem to originate from the assumption that landscape is just an unchanging good to be preserved and that any human action involving it, especially with regards to energy systems, should produce the least possible impact. The starting point intends to be different, as different are also the concept of landscape and the idea of the energy system (ES), which is not

$\overline{3}$ Built for the 1889 Universal Exhibition, it was supposed to be demolished the following year. 
interpreted as a simple plant, but rather as an inseparable blending of the plant and its support, its functions and, as a consequence, the place surrounding it.

It can also be noted that, just as a medieval tower or cultivation, the ES can become landmark or landscape.

The ESs can be considered as landscape when their number and their distribution, ${ }^{4}$ their historical sedimentation $^{5}$ and their perception addiction ${ }^{6}$ makes them recognizable as part of the landscape, where nothing particularly relevant stands out among the rest (Howard et al. 2013; Nadaï and Van der Horst 2010).

However, if an ES is able to emerge in the surrounding landscape and to leave a substantial and detectable mark influencing the entire context and orienting men's perception and movements, then we are dealing with an energy landmark. In this sense, the ES has all the characteristics to be literally considered a marker of land and a reference point (Golledge and Stimson 1987).

This is not a necessarily good thing: sometimes the ESs have positive effects on their area of influence, sometimes they produce a negative impact.

At first, two extremely opposite categories representing the relations between ESs and their area can certainly be identified: static-conservative and energocratic. The former embodies the victory of the existing (whether natural, para-natural or historically consolidated) on the new $\mathrm{ES}$; the latter is the positivistic affirmation of the new on the existing, absolutely insensitive to all possible modifications (Ritter and Venturi Ferriolo 1994).

A significant example of the static-conservative category can be the absolute subjection of energy systems towards historical or protected buildings, where the ES is introduced as an absolute necessity, but at the same time must be the least visible. This is the case of listed buildings or places considered "untouchable": here, with a certain hypocrisy, the presence of an ES is accepted only if very discreet or, better yet, out of sight; otherwise, the landscapethe observers-would think of it as a misrepresentative object, lodged where it does not belong. One example is the Paul VI Hall in Vatican City, covered with hundreds of photovoltaic tiles which are totally invisible to anyone who is not at the same height as the dome of Michelangelo.

On the other hand, the energocratic category covers all those cases where economic needs/regulations take especially technical aspects into consideration, so that ESs are shown off with the sole aim of producing the highest profit, directly and immediately. This is often the product of the action of the individual or a few, with purely economic personal goals.

\footnotetext{
${ }^{4}$ Such as the transport of electricity pylons.

5 The hydroelectric power plants of the early 900 .

6 TV antennae on house roofs.
}

For example, the 1987 big solar furnace of Tashkent, Uzbekistan, is a huge facility for solar concentration where even the figurative aspect is significantly iconic of its aggressive and assertive bearing with respect to the surrounding landscape.

This initial categorization certainly appears to include all the ESs, but it may be further articulated to outline other useful categories for the definition of design and landscape programming guidelines (Stremke and Van den Dobbelsteen 2013). For this reason, it was necessary to introduce an analysis method for the definition of categories which can provide more detailed and advanced interpretation keys. The ES should not be viewed as something "other" that must necessarily be hidden, exhibited, mediated or reluctantly accepted. ESs have their own dignity and play a part in active and conscious landscape design (Raymond et al. 2017): that is why the question should not be posed in terms of conflict, but rather in terms of synergy; not of oppression, but of constructive dialogue (Potthoff 2007).

Therefore, the following paragraphs show the indicators and factors which can help generating consistent and informed decisions related to the overall judgment on ESs, by introducing interpretation categories providing more detailed and advanced understanding. Firstly, the dynamic relationship between ESs and its surrounding landscape will be examined, outlining a method to define which specific system can be positive and suitable for a given territory.

\section{Method}

\section{The information apparatus for the analysis of energy system territory}

An articulated and active analysis of energy systems, which overcomes the contrast described above, has to start from a structure of the information system for the analysis of energy systems itself.

The design of the method provides a definition of parameters enabling the gathering, targeted selection and subsequent classification of case studies. The parameters present four kinds of case study information, graphically represented by the following table.

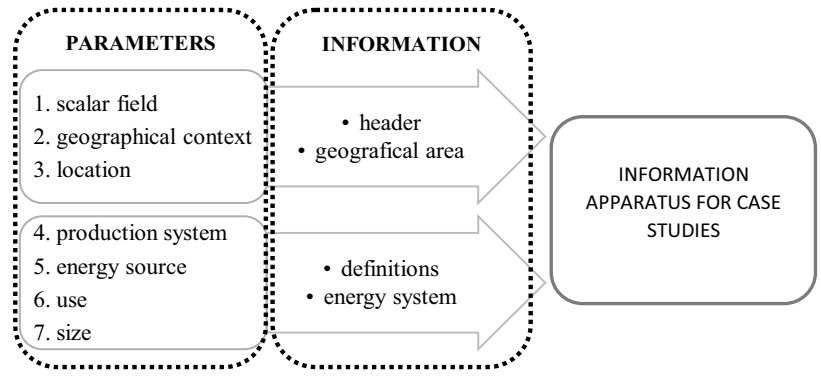


The first analysis parameter is the scalar field. It identifies the relationship between the energy system and the users of produced energy. It may refer to the territorial scale (the energy produced is intended for large-scale distribution), the urban scale (the energy produced is distributed in the neighborhood) or the housing body scale and/or the structure (the energy produced is used captively for individual buildings and/or the individual artifact itself).

The second parameter is the geographical context, interpreted as the morphology and the type of area where the energy system is situated.

It may belong to: natural areas, where man has not changed any structural, functional and morphological component and where there are no human settlement processes in place; rural/para-natural areas, where mankind has changed one or more functional, morphological and structural components and where there can be taking place human interventions of a limited extent; rural areas with a high level of biodiversity, where man has made serious changes to the biotic and abiotic structure and where the ecological functions are oriented to maximize food production for humans or animal breeding; rural areas with a low level of biodiversity, where human intervention has been more intense and extended so there is a smaller vegetation apparatus; peri-urban areas, where both urban and industrial para-natural characters are recognizable; urban areas, where mankind has profoundly altered the biotic and abiotic structure and where the ecological functions and the flow of energy and matter are geared to ensure the performance of functions and human activities such as living, production, trade and transport; and industrial areas, where man has totally changed the biotic and abiotic structure and where the ecological functions and the flow of energy and matter are geared to conduct productive activities.

The third parameter is the location, which may be on land (systems positioned directly on the ground or on buildings/artifacts) or in the sea, either outside the water (floating systems or partially out of the water) or on the sea bottom (systems anchored to the sea floor, invisible from the surface).

The fifth parameter is the energy source, divided into: direct solar heat (use of direct solar radiation to produce hot water); solar heat for concentration (use of solar radiation mediated by mirrors and concentrators to produce superheated fluids generating electricity); solar photovoltaics (production of electricity from direct solar radiation); water for hydroelectric power plants (large power plants (MW of the order) harnessing big jumps in water level to produce electricity); tidal currents and water (kinetic energy, use of tides and currents to produce electricity); water for mini-hydro (use of minor jumps to produce electricity on a small scale); water for mills (use of small jumps to produce direct kinetic energy); wind energy (use of wind to produce electricity); active geothermal energy (heat production through the use of heat pumps); passive geothermal energy (use of geothermal heat for the spontaneous production of electricity); hydrogen (production, storage and transport of hydrogen as an energy carrier); kinetic movements (use of small quantities of kinetic energy to generate electricity for their own consumption); waste (or direct combustion of waste materials, waste and biomass for the production of electricity, often combined with heat production); fossil resources (burning of fossil resources for the production of electricity and/or heat).

The fourth parameter is the production system, defined as the relation among the systems to produce energy. Such system can be widespread and designed to be reiterated through independent elements, or concentrated and geographically localized, thus born to be an independent element of a network, which may be present for the subsequent transport of produced energy.

The sixth parameter is the use, defined as the destination of produced energy: it may be meant for self-production (a system conceived for the production of energy only addressed to the consumption, or power consumption, of a directly connected user) or export (a system designed for the production of energy destined to remote users, which requires a dedicated energy transport system).

The seventh parameter is the size, understood as power in relation to the possibilities of the current production techniques system: it can be $\mathrm{S}$ (minimum installable power from a technical point of view); M (medium power usually installed for that kind of system); L (large power system, generally above the average installed power); or $\mathrm{XL}$ (maximum power installed in a given case).

This series of parameters allow the structuring of an information system able to place any case study within its reference scenario, creating an information sheet organized in four parts:

- Heading information: provides the specific case study position within the scenario of reference cases and detects the consistency and the specific nature of the case;

- Geographical area: identifies the context where the energy system is placed, through climatic, energetic, landscape and geographical parameters;

- Definition of the case study: in addition to energy source data, other factors such as technical/physical data, intervention type, production data, degree of 
reversibility, involved players, procedures and realization process and year of implementation are also provided;

- Energy system: precisely expresses the specific characteristics of the analyzed and contextualized system.

This would result in providing information on the ES according to its relationship with the area and the surrounding context/building as well as techno-typological detailed data.

\section{Results and discussion}

\section{For a functional and perceptual classification}

From the analysis of the case studies - meaning both general plant system categories and ES, framed in a purposebuilt information apparatus-common denominators have emerged which are able to bring out those cases that, more than others, have been favorably welcomed by the plurality of stakeholders, or taken as examples and best practices. Within this operation, numerous data have given rise to the definition of functional categories which led to a "perceptive" classification of the analyzed cases. These cases have been synthesized and summarized in the following table, creating general categories and sub-categories. Please note that the examples are not exhaustive of the class but were considered significant to explain, through images, the illustrated concept.

\begin{tabular}{llll}
\hline Categories & Sub-categories & Specifications & Case studies \\
\hline Visibility & Visible & $\begin{array}{c}\text { Visible ES from } \\
\text { public spaces }\end{array}$ & Figure 1 \\
& Invisible & $\begin{array}{c}\text { Non visible ES from } \\
\text { public spaces }\end{array}$ & Figure 2 \\
& & public & \\
\hline
\end{tabular}

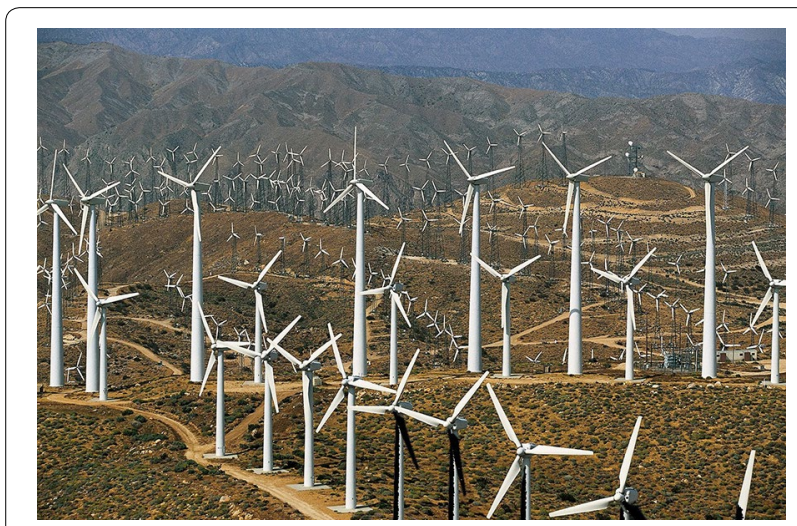

Fig. 1 Wind turbines: exposed and visible (from http://www.yanna rthusbertrand2.org)

\begin{tabular}{|c|c|c|c|}
\hline Categories & Sub-categories & Specifications & Case studies \\
\hline \multirow[t]{4}{*}{ Time (age) } & $\begin{array}{l}\text { Historical } \\
\text { archaeology }\end{array}$ & $>150$ years & Figure 3 \\
\hline & $\begin{array}{l}\text { Industrial } \\
\text { archaeology }\end{array}$ & 150 years $>30$ years & Figure 4 \\
\hline & Contemporary & $>30$ years & $\begin{array}{l}\text { The majority of } \\
\text { RES (Renewable } \\
\text { Energy System) }\end{array}$ \\
\hline & New systems & $\begin{array}{l}\text { Prototypes or } \\
\text { experimental }\end{array}$ & $\begin{array}{l}\text { There are many } \\
\text { cases of RES that } \\
\text { had experi- } \\
\text { enced a large } \\
\text { media launch, } \\
\text { but for which } \\
\text { there is no trace } \\
\text { in the current } \\
\text { production }\end{array}$ \\
\hline
\end{tabular}

\begin{tabular}{llll}
\hline Categories & Sub-categories & Specifications & Case studies \\
\hline $\begin{array}{c}\text { Time (dura- } \\
\text { tion) }=\text { tras- }\end{array}$ & Temporariness & Transportability & Figure 5 \\
portability & Short duration & Disassemblable & Figure 6 \\
& Stability & $\begin{array}{c}\text { Non transport- } \\
\text { ability }\end{array}$ & $\begin{array}{c}\text { The majority of } \\
\text { RES }\end{array}$ \\
\hline
\end{tabular}

\begin{tabular}{|c|c|c|c|}
\hline Categories & Sub-categories & Specifications & Case studies \\
\hline \multirow{3}{*}{$\begin{array}{l}\text { Level of anthropo- } \\
\text { genic stratifica- } \\
\text { tion }\end{array}$} & New & & Figure 7 \\
\hline & $\begin{array}{l}\text { Building requalifica- } \\
\text { tion }\end{array}$ & & Figure 8 \\
\hline & $\begin{array}{l}\text { Urban requalifica- } \\
\text { tion }\end{array}$ & & Figure 9 \\
\hline
\end{tabular}

\begin{tabular}{|c|c|c|c|}
\hline Categories & Sub-categories & Specifications & Case studies \\
\hline \multirow[t]{4}{*}{ Manufacturability (size) } & Small & & Figure 10 \\
\hline & Medium & & Figure 11 \\
\hline & Large & & Figure 12 \\
\hline & Extra large & & Figure 13 \\
\hline
\end{tabular}

\begin{tabular}{llll}
\hline Categories & Sub-categories & Specifications & Case studies \\
\hline Usability & Practicability & In paths & Figure 14 \\
& Protection & $\begin{array}{c}\text { As covering, railing, guard } \\
\text { rails, gutters }\end{array}$ & Figure 15 \\
& Walkability & $\begin{array}{c}\text { Systems exploiting the } \\
\text { kinetic energy of vehi- } \\
\text { cles and/or pedestrians }\end{array}$ & Figure 16 \\
& &
\end{tabular}

\begin{tabular}{llll}
\hline Categories & Sub-categories & Specifications & Case studies \\
\hline Physical proximity & Proximity & $\begin{array}{c}\text { To the built envi- } \\
\text { ronment }\end{array}$ & Figure 17 \\
& Distance & $\begin{array}{c}\text { From the built } \\
\text { environment }\end{array}$ & Figure 18 \\
\hline
\end{tabular}




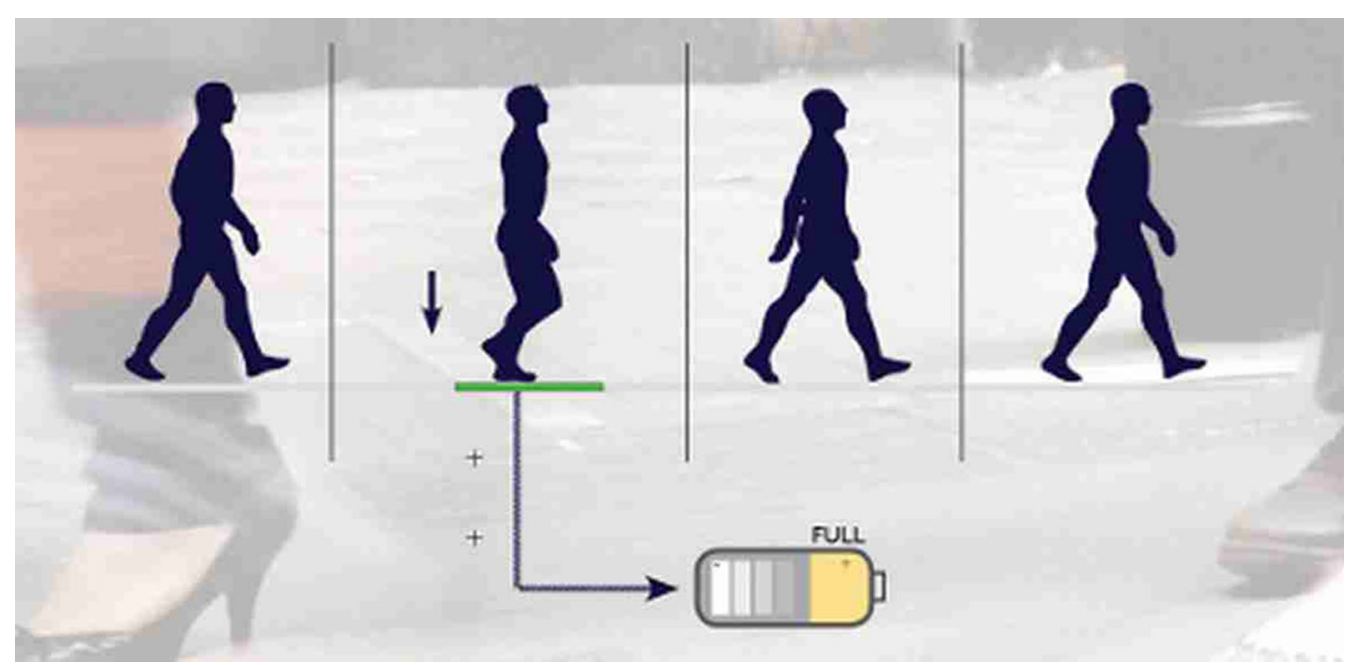

Fig. 2 Kinetic energy systems positioned on the ground (from http://www.pavegen.com)

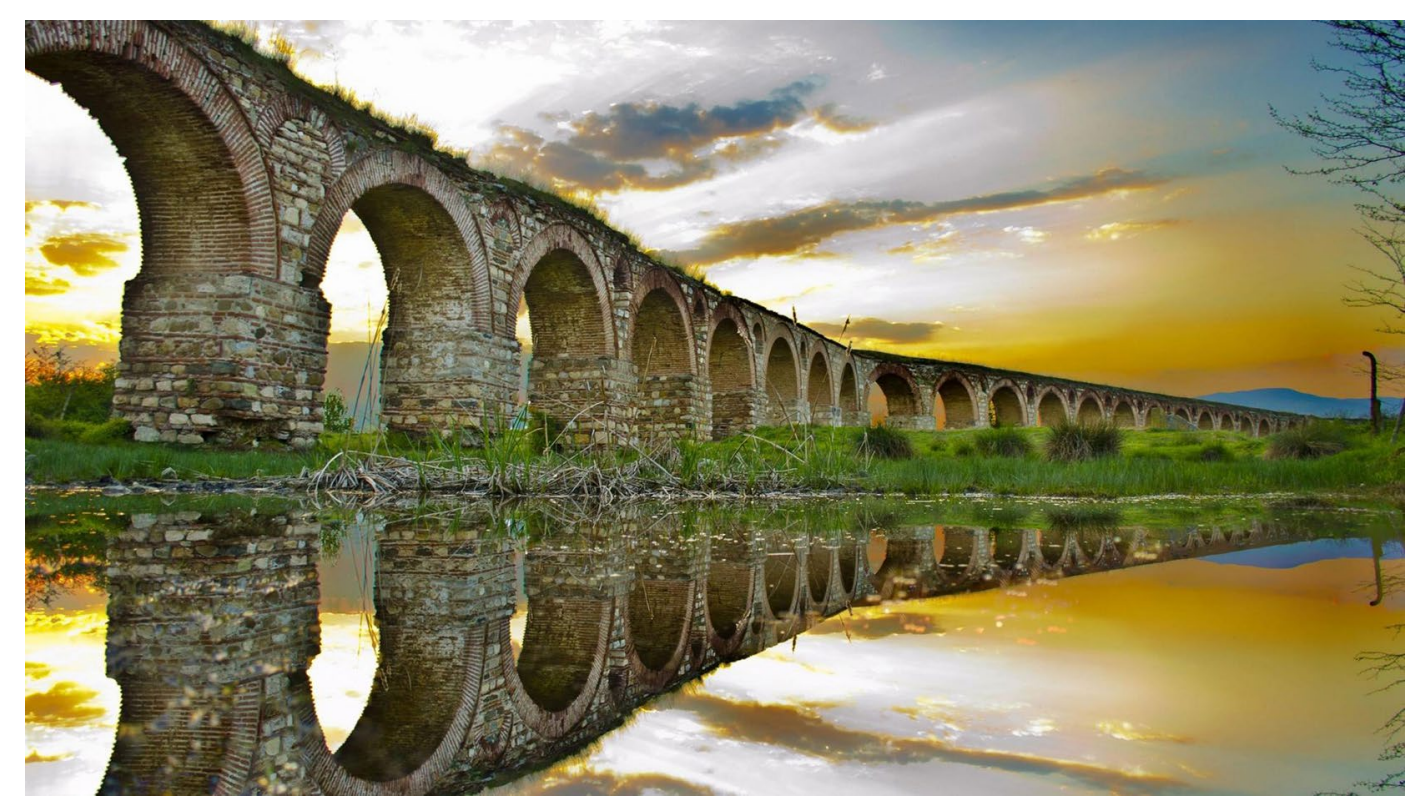

Fig. 3 Roman aqueducts near Rome (from http://www.acquacampania.com). Other examples: Dutch mills, salt marshes, etc.

\begin{tabular}{|c|c|c|c|}
\hline Categories & Sub-categories & Specifications & Case studies \\
\hline \multirow[t]{2}{*}{ Decisional proximity } & Top down & & Figure 19 \\
\hline & Bottom up & & Figure 20 \\
\hline
\end{tabular}

\begin{tabular}{llll}
\hline Categories & Sub-categories & Specifications & Case studies \\
\hline Appearance & $\begin{array}{c}\text { Care for the building } \\
\text { envelope } \\
\text { "Basic" building envelope } \\
\text { considering only } \\
\text { engineering needs }\end{array}$ & Figure 21 \\
& Figure 22 \\
\hline
\end{tabular}

\begin{tabular}{|c|c|c|c|}
\hline Categories & Sub-categories & Specifications & Case studies \\
\hline \multirow[t]{3}{*}{ target } & $\begin{array}{l}\text { Demonstrative/didactic/ } \\
\text { iconic }\end{array}$ & & Figure 23 \\
\hline & Economic/energetic & & Figure 24 \\
\hline & Regulatory compliance & & Figure 25 \\
\hline Categories & Sub-categories & Specifications & Case studies \\
\hline \multirow[t]{2}{*}{ Functionality } & Monofunctional & & Figure 26 \\
\hline & Multifunctional & & Figure 27 \\
\hline
\end{tabular}




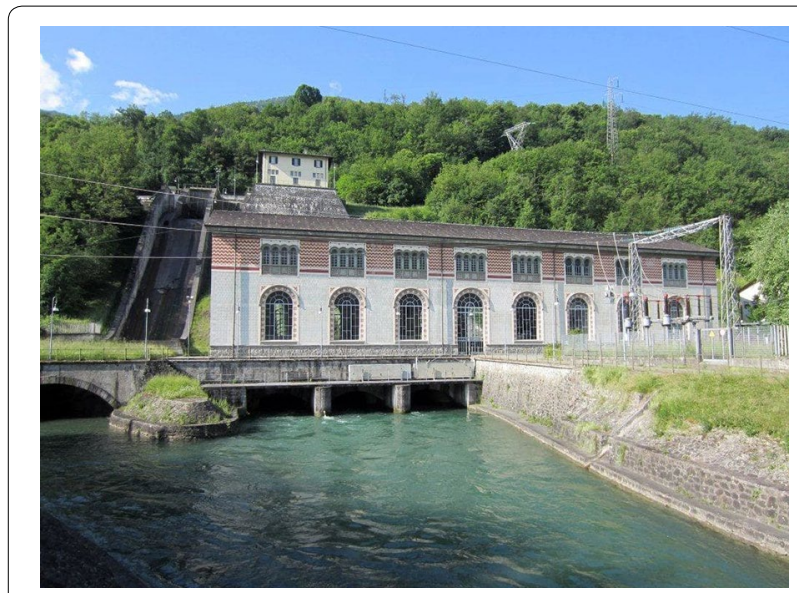

Fig. 4 Historical hydropower plants: in this case Valchiavenna (from www.sondriotoday.it)

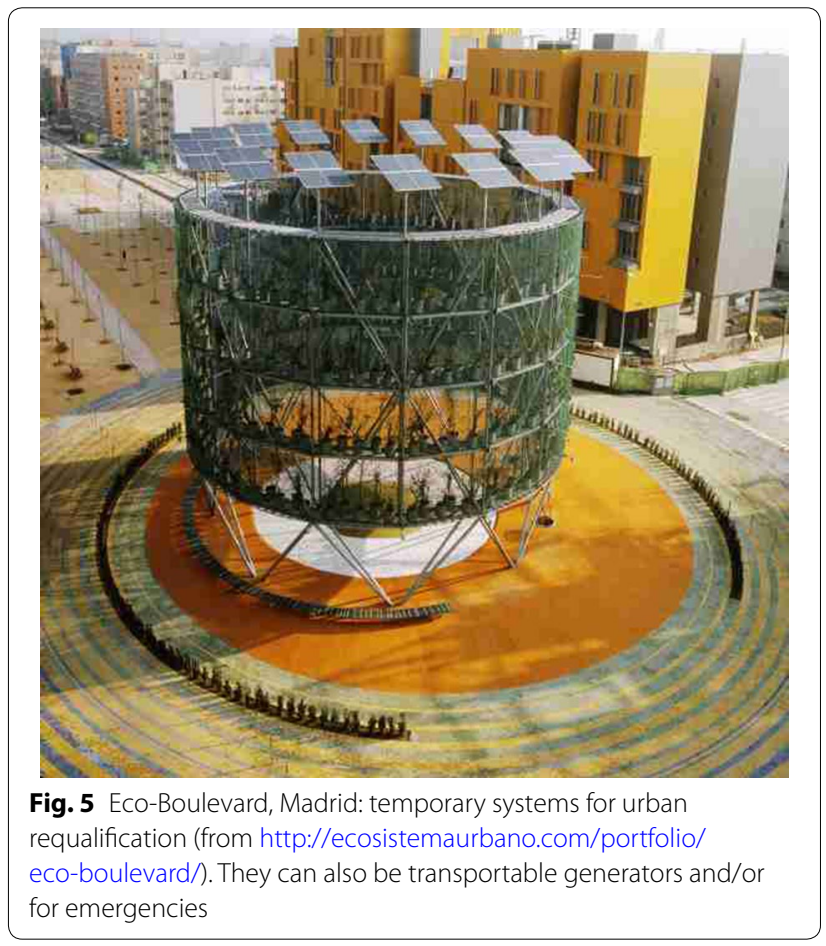

The table above clarifies some categories which may be used in the classification of ESs from the point of view of their perception. The different, general categories exposed are commented as follows:

\section{Visibility}

An invisible ES is not necessarily well accepted: the choice of assigning resources for an invisible object could not be appreciated if the purpose of the intervention is to promote renewable energy, to publicize stakeholders' actions or to be iconic and easily recognizable.

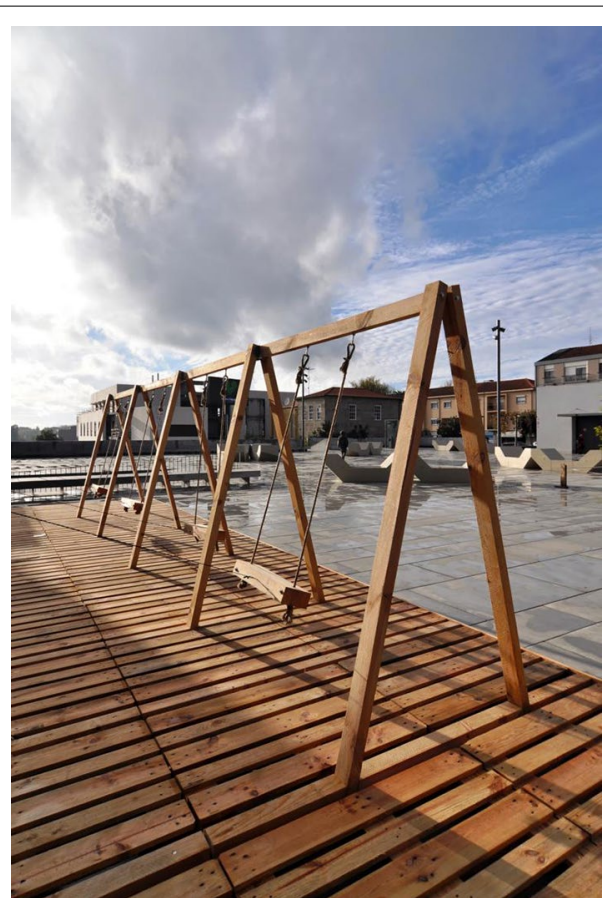

Fig. 6 Temporary and demonstrative systems: Moradavaga SWING, electricity generation swing (from http://www.moradavaga.com)

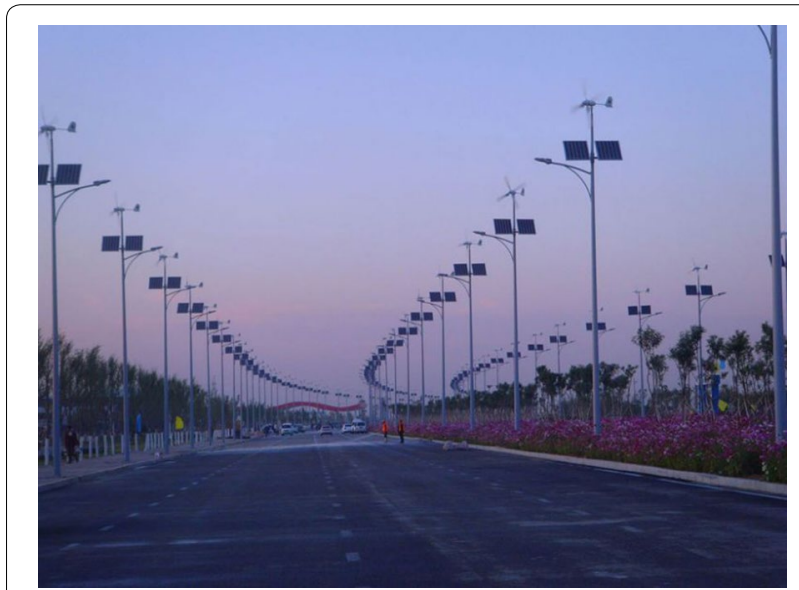

Fig. 7 OFF-grid street lamps at Bargallò, Spain (http://www.walln ews24.it/2018/01/04/santomero-convenzione-attivata-pali-fotovoltai ci-dellilluminazione-pubblica/)

\section{Time (age)}

Since landscape retains a great inertia, ${ }^{7}$ those ESs that have been part of the landscape for a long time are

\footnotetext{
${ }^{7}$ In physics, the property of inertia causes objects to resist to status variation; in the same way, a landscape which remains in stasis for a long time struggles to accept changes.
} 


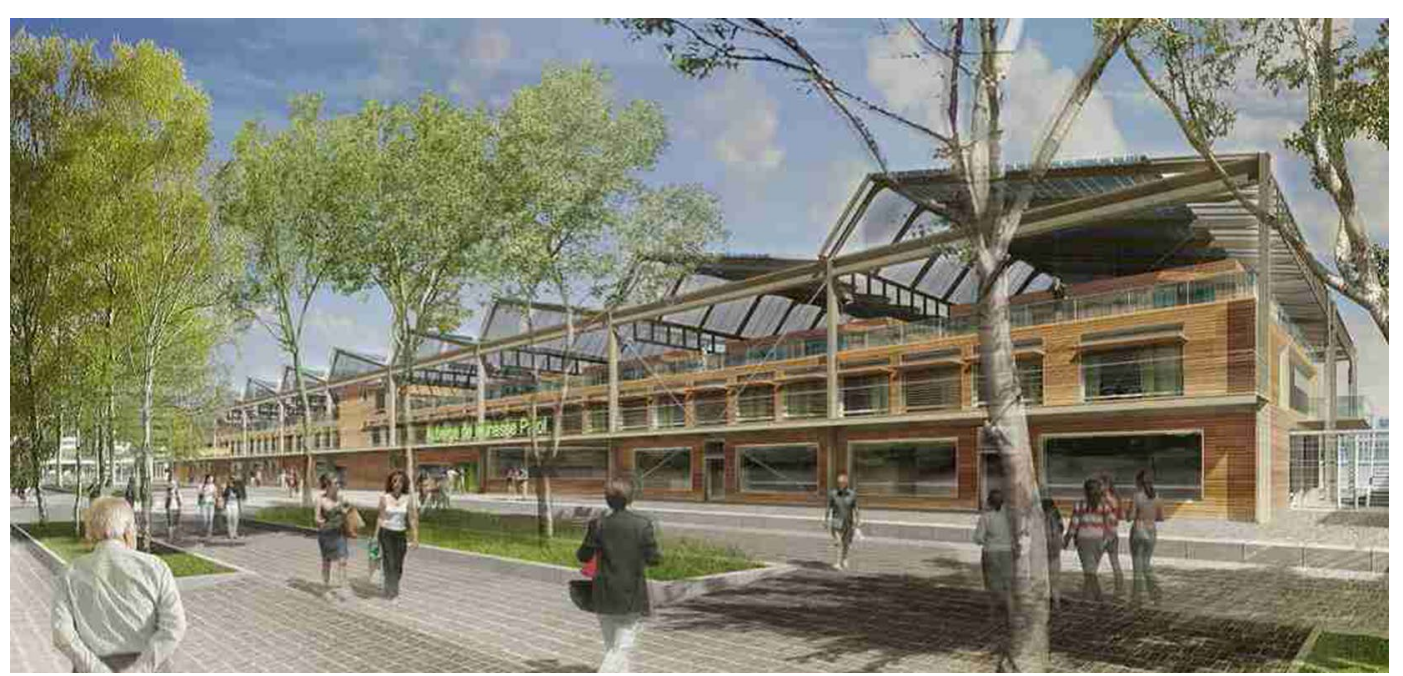

Fig. 8 Requalification of abandoned warehouse Halle Pajol, Paris (from http://www.jourda-architectes.com)

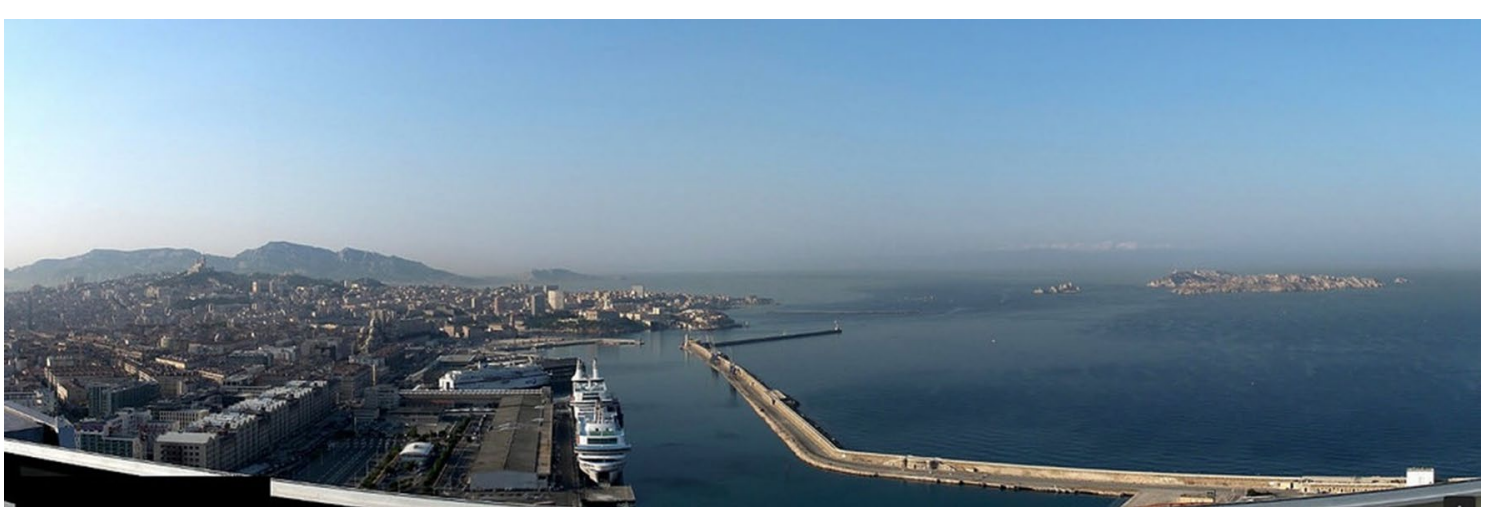

Fig. 9 Requalification of a neighborhood in Marseille (FR) through ocean thermal energy (http://www.pss-archi.eu)

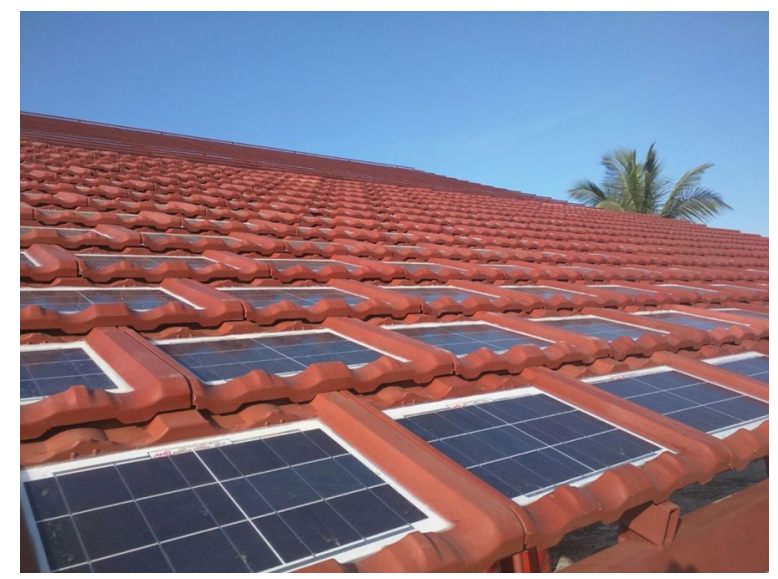

Fig. 10 Photovoltaic tile (from http://anusolar.com)

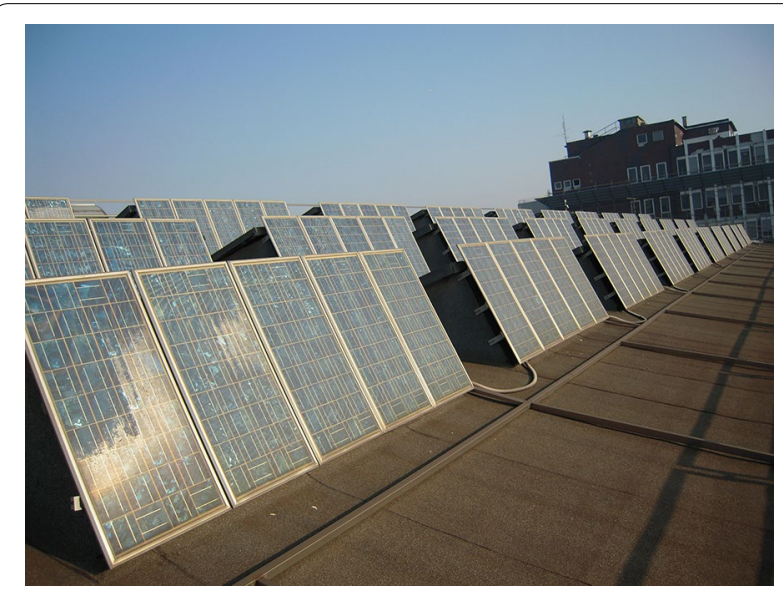

Fig. 11 Photovoltaic plant of medium size (Library roof plant of Politecnico of Milano. Picture by authors) 


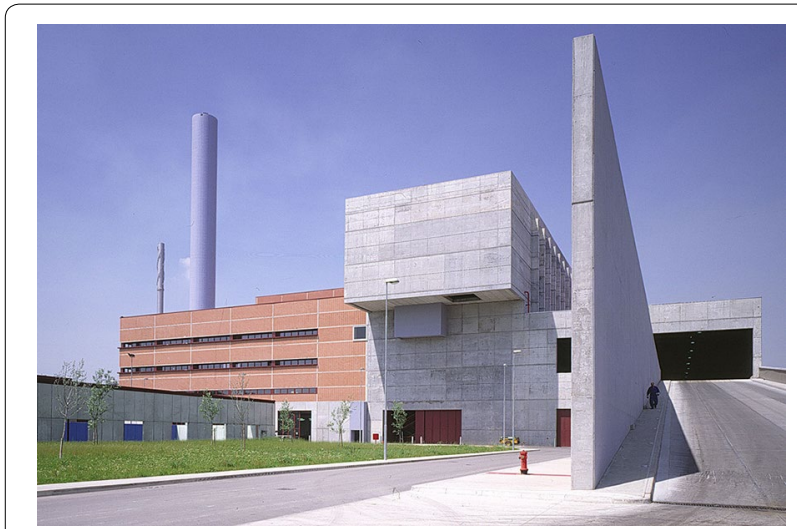

Fig. 12 Waste-to-energy tele-heating system Silla 2 in Milan (from http://www.a2a.it)

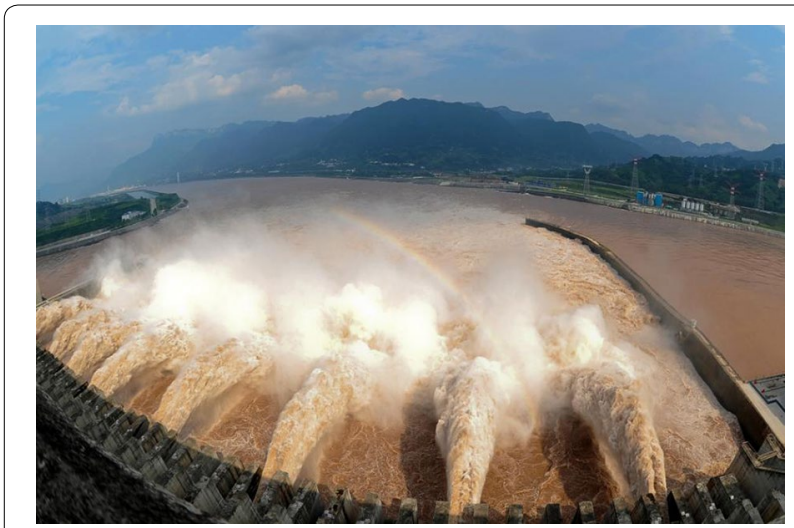

Fig. 13 The three gorges dam on the Yangtze River in Hubei, China (from http://www.rinnovabili.it)

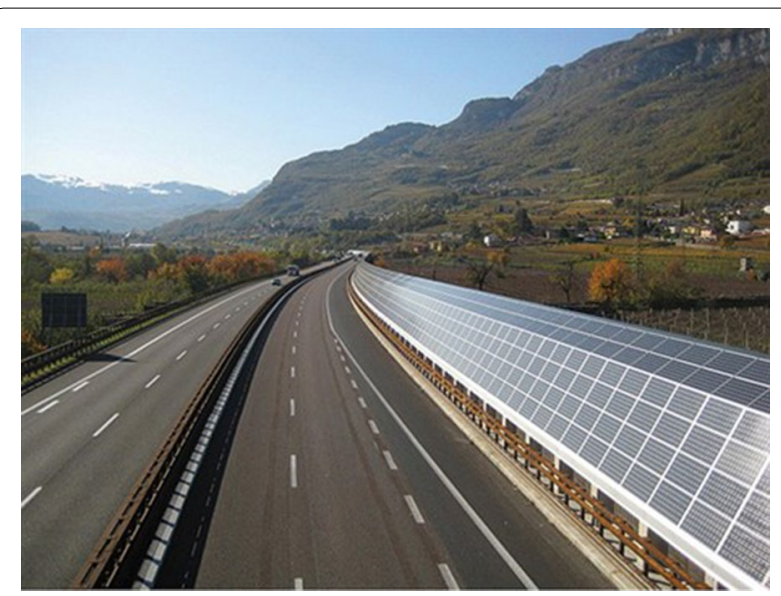

Fig. 15 Photovoltaic railing and guardrails photovoltaic parkings. (Here the Brennero highway in Italy from http://www.autobrennero.it)

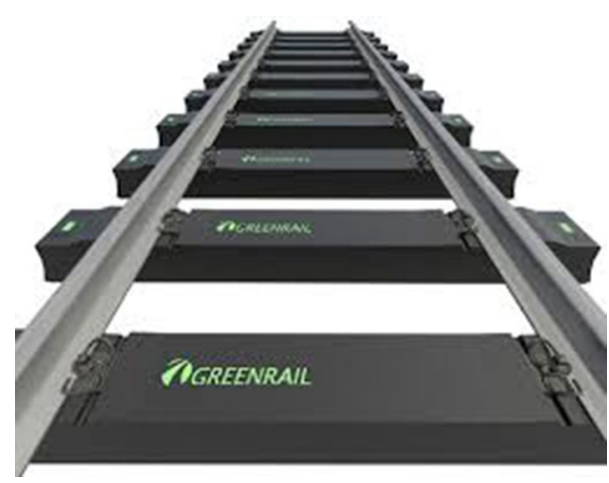

Fig. 16 Greenrail: railroad ties that generate electricity to the passing of trains (from http://www.greenrail.it)

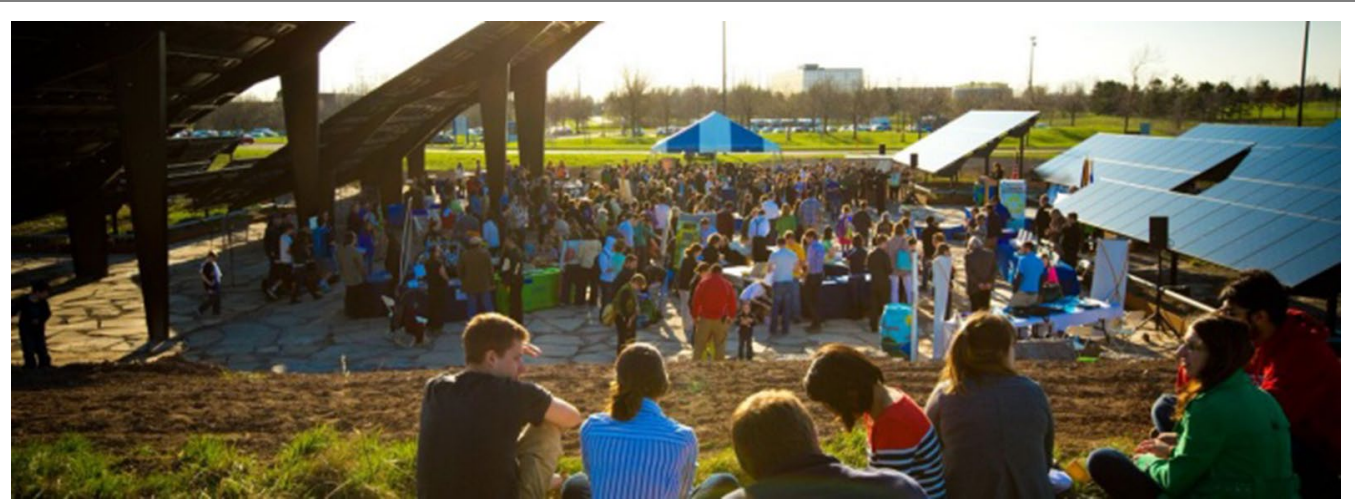

Fig. 14 Buffalo Solar Strand: photovoltaic park with classrooms and outdoor paths (from http://www.buffalo.edu) 


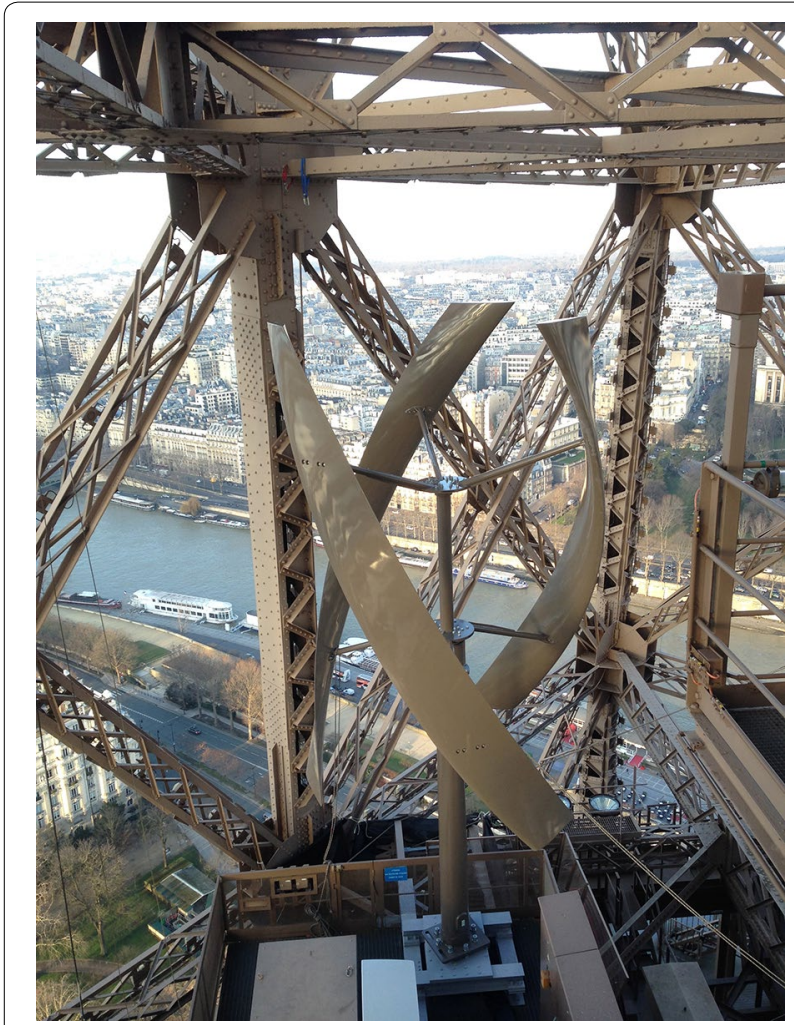

Fig. 17 Wind turbine on the Tour Eiffel, Paris (from http://www.sunwi ndenergy.com)

perceived as an integral part of landscape itself. Contrariwise, whatever gets introduced quickly or simultaneously is recognized by the observer as extraneous and negative. Each transformation should therefore be slow and

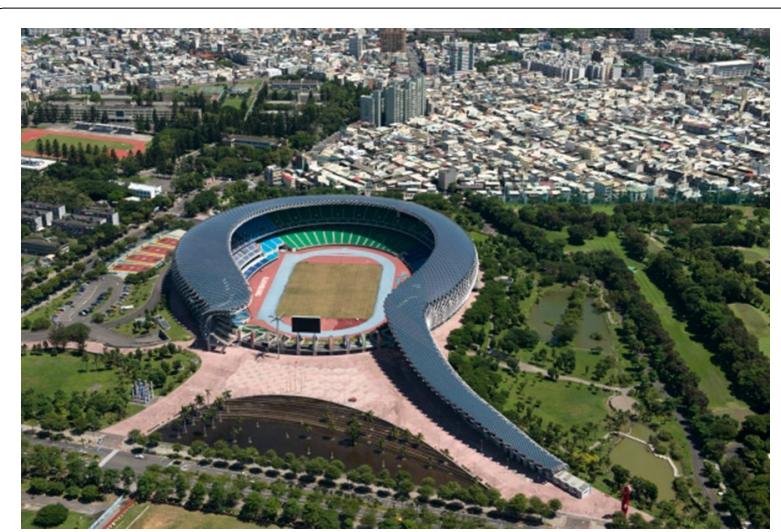

Fig. 19 Kaoshiung stadium, T. Ito, 2009, Kaoshiung, Taiwan (from https://k720.kcg.gov.tw)

gradual (with the appropriate involvement and participation of the population).

\section{Time (duration) $=$ transportability}

This category is closely linked to the concept of transportability. If we consider time as duration, it is clear that a temporary intervention responding to targeted needs for short periods is always likely to be welcomed better than long-lasting or permanent interventions. Conversely, temporary interventions often imply much higher economic and management costs making them less attractive.

\section{Level of anthropogenic stratification}

This category attempts to clarify the relationship between the ES and the place/support where it is placed. The

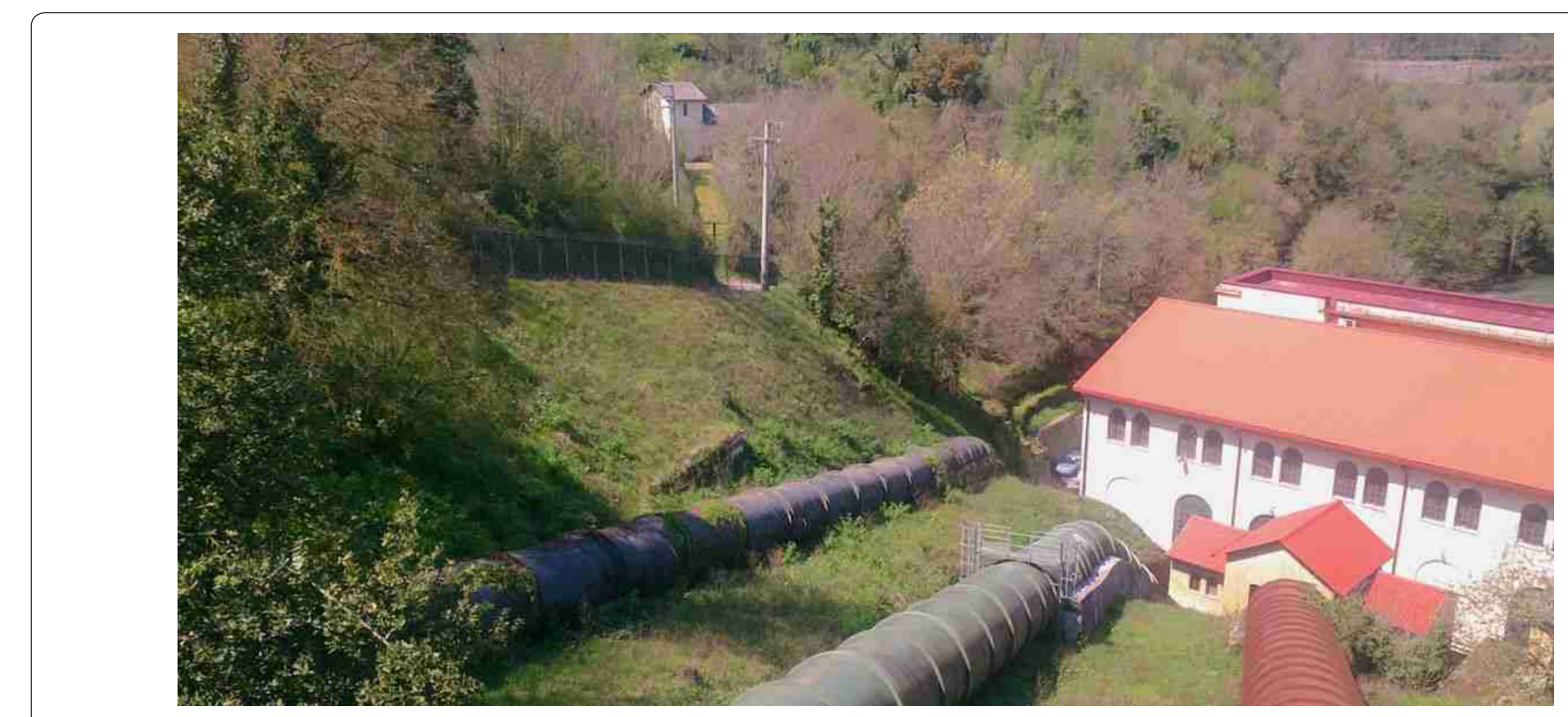

Fig. 18 Hydroelectric plant in Castel Madama IT (from www.atbrc.com) 


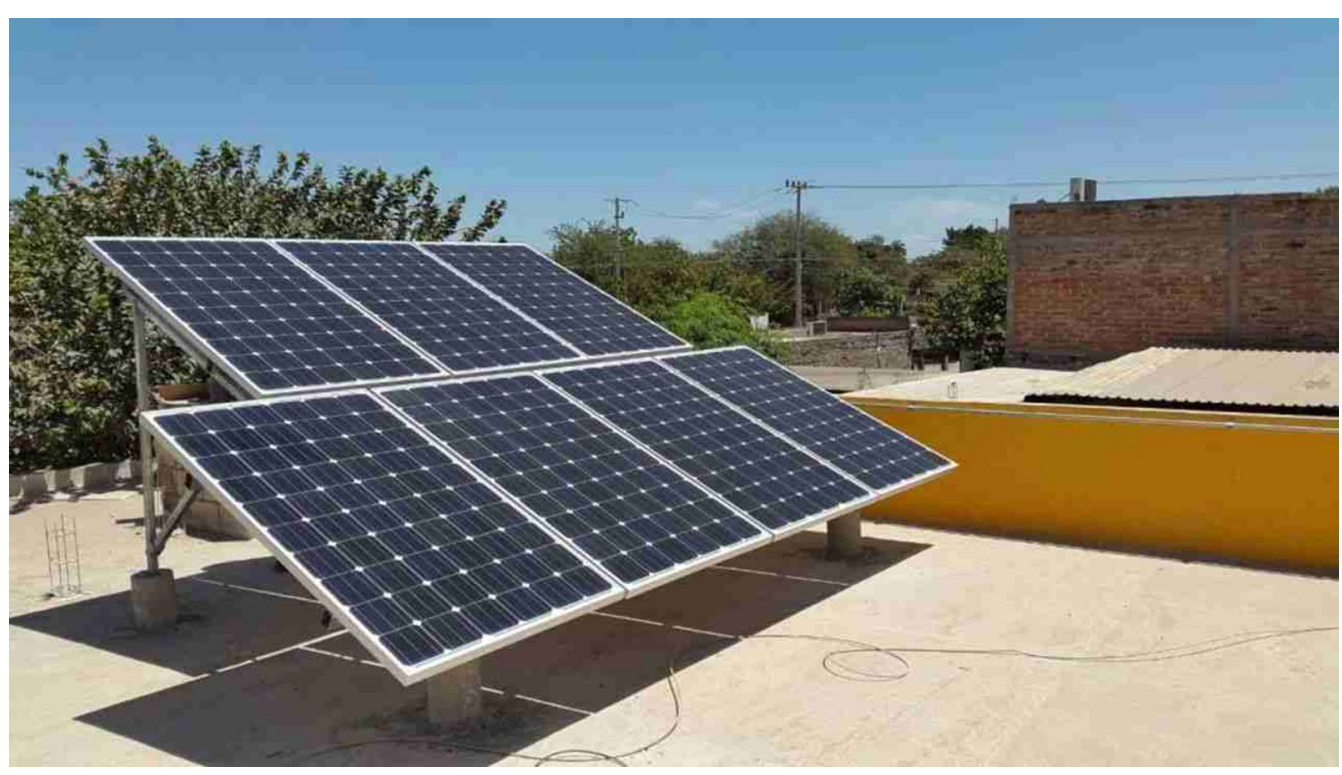

Fig. 20 Cooperative photovoltaic panels in Melpignano, Puglia, IT (from http://www.coopcomunitamelpignano.it)

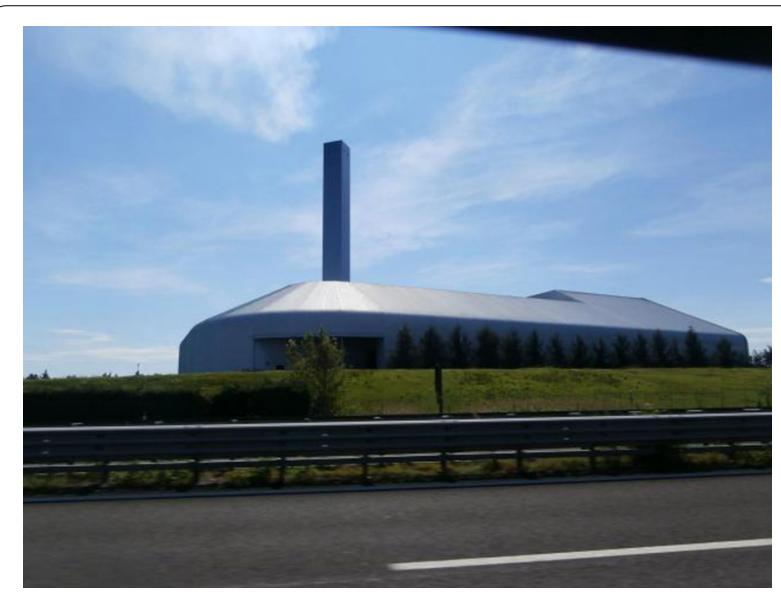

Fig. 21 Waste-to-energy incinerator in Brescia, IT: particular attention to the envelope and chimney (from http://www.a2a.it). To this category also belong all cases of rehabilitation of old plants

introduction of an ES from scratch, especially in fragile and stratified areas, is almost always the most critical choice. The ES can and should be an opportunity to regenerate an area, a neighborhood or a building, facing the proposed project not only as a location for a new facility, but also as a chance to insert an object creating profitable relationships within that area.

\section{Manufacturability (size)}

The size determines, for most energy systems, the problems and the potentials linked to the ES dimensions (in terms of physical size and power): for each size, the

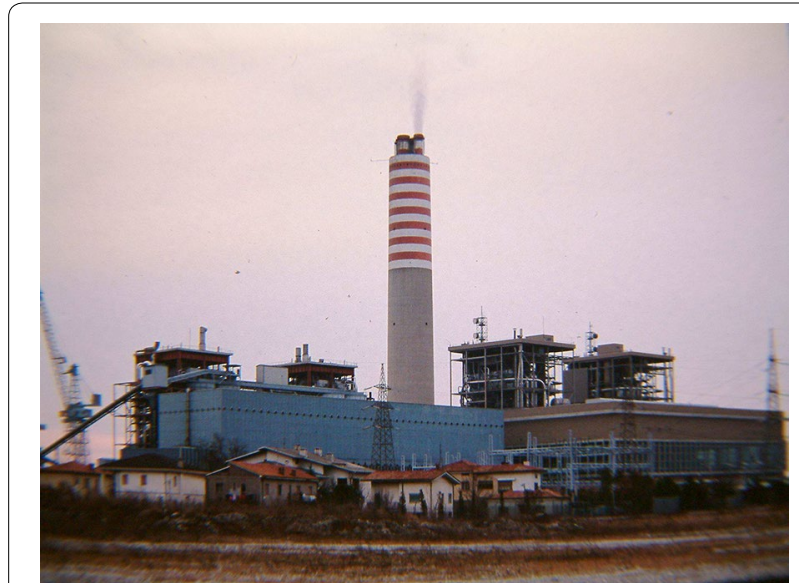

Fig. 22 Thermoelectric plant in Monfalcone, IT (from http://www. a2a.it)

bonds and relationships established with landscape are different and sometimes conflictual, so that the variation of size can modify the perception and the quality of the intervention. The size of an ES is a key element in the evaluation of its impact: the optimal size, on a purely engineering basis, is not always the best for the area where the ES is situated. The current trend goes towards small-sized ESs, linked to each other in a network, able to gather more support and to reduce the possible negative effects connected with energy concentration. 


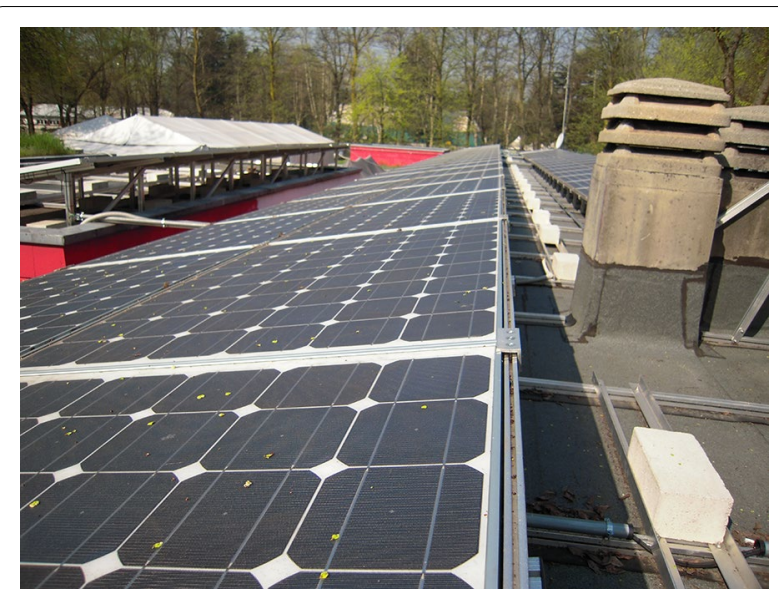

Fig. 23 Photovoltaic panels on the roofing of Circolo Magnolia (Milan, IT): because of a non optimal performance and placement, the project was primarily meant for marketing (picture of the authors)

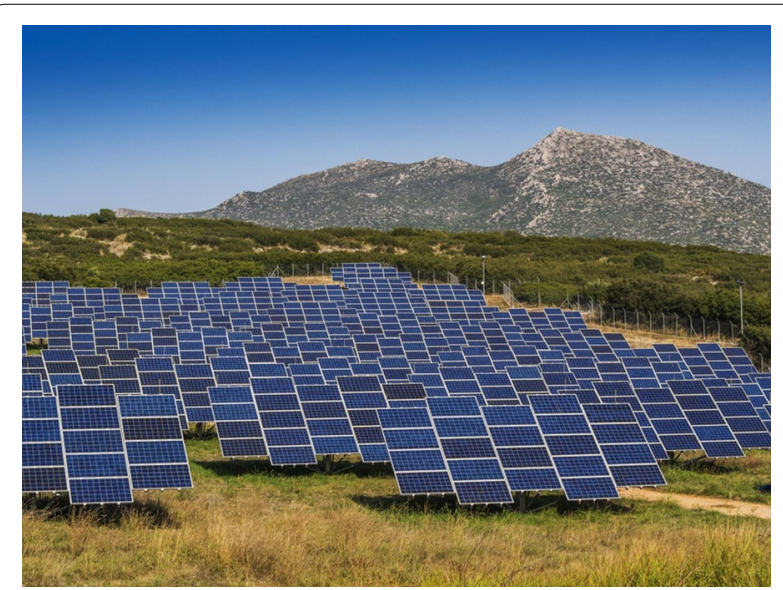

Fig. 24 Photovoltaic park in the countryside in Lombardy, IT (from www.vigilanzagroup.it)

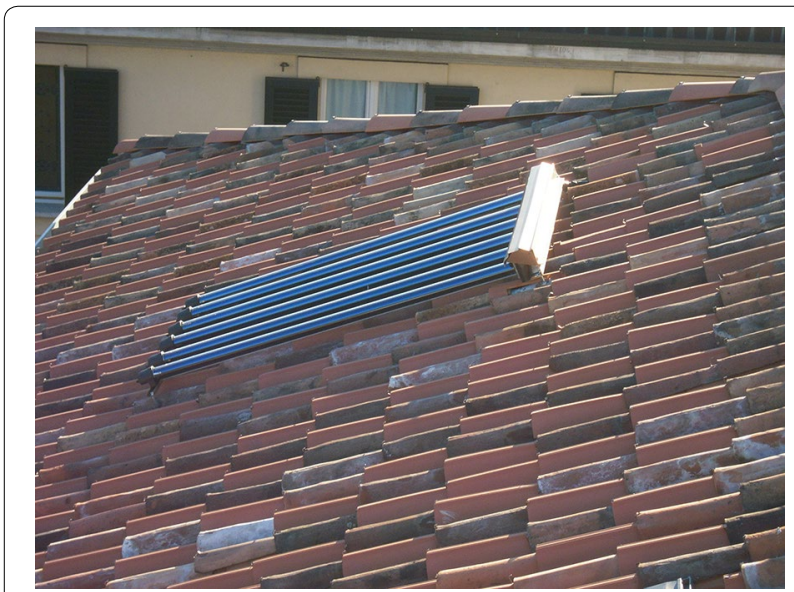

Fig. 25 Solar thermic panel on the roofing: regulatory requirement for the production of hot water (picture by authors)

\section{Usability}

The ESs are not simply technical systems: they are necessarily objects, which can offer other benefits. They can provide shade and shelter from the rain, can protect from falls or noise or may form floors to walk on.

\section{Physical proximity}

NIMBY phenomena often pose the main obstacle to the new ESs: everyone is ready to support the needs of modern and useful plants, but the further from one's home and neighborhood, the better (Nijkamp 2008).

\section{Decisional proximity}

Think global, act local: the acceptance of an ES depends on whether the people involved in decision making acknowledge the changes it implies, in a positive or negative direction (what can I give up to get more) (Van Der Horst and Vermeylen 2011).

\section{Appearance}

The architectural design of the first hydroelectric power stations were entrusted to Italian great architects (Piero Portaluppi and Gio Ponti among all). After that, unfortunately, the power stations no longer met the need to give the architectural object a special attention, considering only plant and engineering needs. In recent years there has been a comeback to the care for ESs: the redevelopment of a plant now includes also the rehabilitation of the building envelope, so that appearance plays a key role as an interface with landscape. It is also true, however, that sometimes these operations are pure green-washing, aimed mostly at addressing more attention to the "body" rather than to the content of an ES.

\section{Target}

Every ES has itself the opportunity to pursue multiple objectives: the basis is necessarily composed by economic and energy aspects, along with regulatory compliance. Some interventions may not entail a sustainable energy or economic efficiency, as they have been created with the purpose-not always explicit-to be in some way didactic interventions, where the expected results are not directly economic- or energy-oriented.

\section{Functionality}

A plant system is usually only monofunctional.

An ES must be multi-functional: it must be able to directly/indirectly attract or generate synergies and secondary functions that justify the presence, investment and costs, and that will have returns in terms of global surplus value, not only for the investor, but also for all the citizens. 


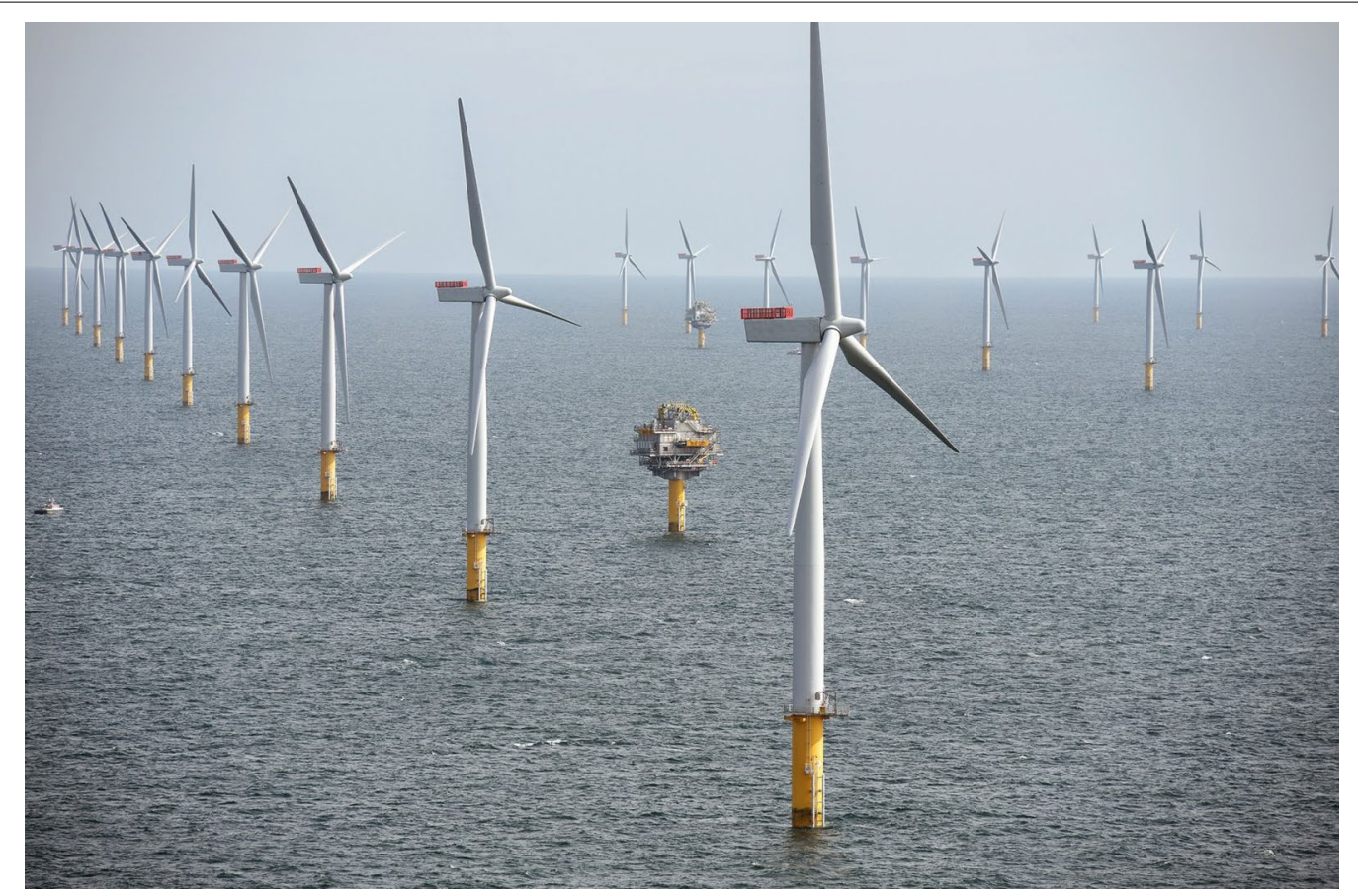

Fig. 26 Off shore wind turbines, Thanet Wind Farm, Thanet Disctrict (Kent), UK (from http://www.theguardian.com)

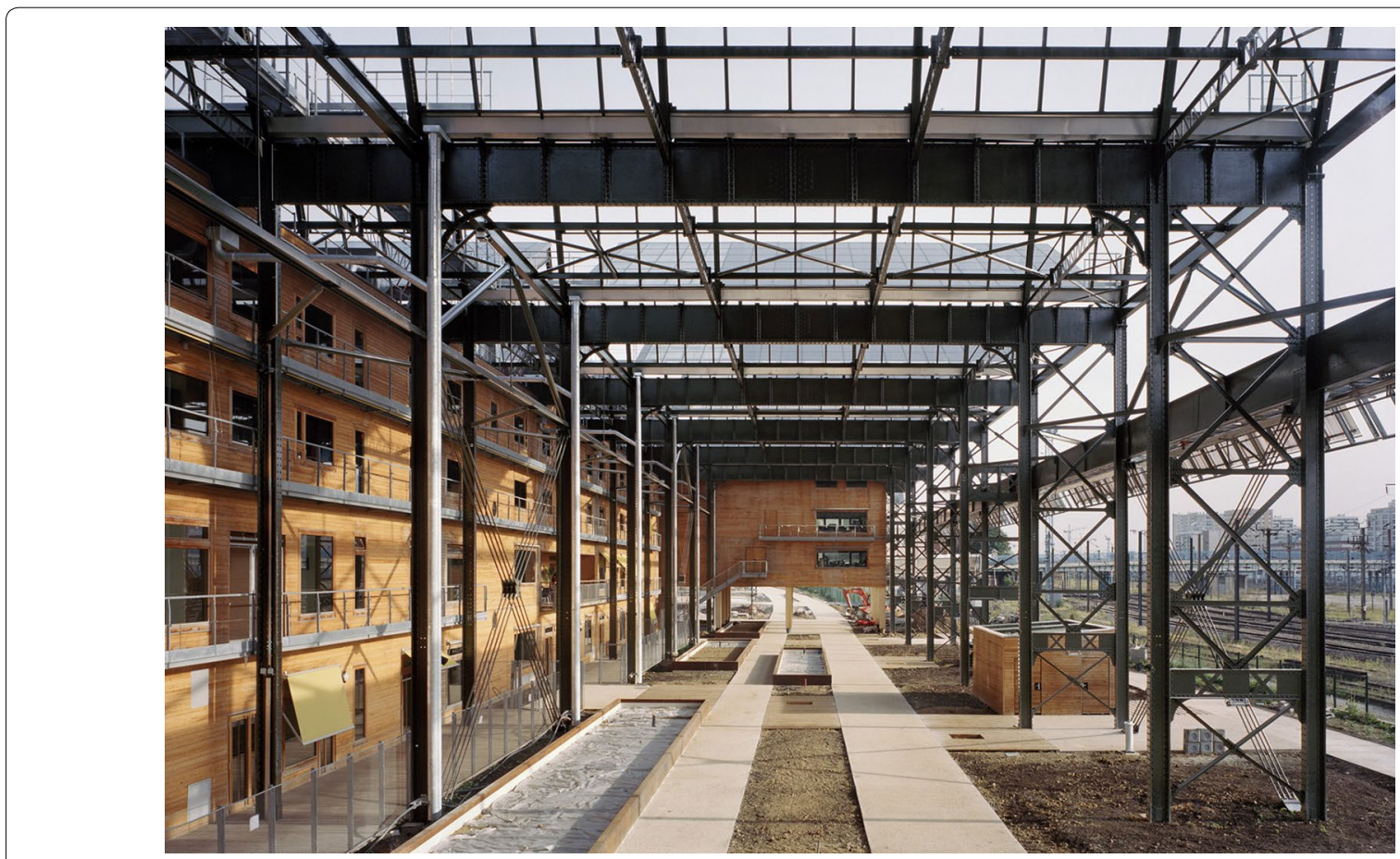

Fig. 27 Requalification of abandoned warehouse Halle Pajol in Paris with the inclusion of multiple public and private functions: the photovoltaic roof shelters also open spaces for orchards and common areas (from http://www.jourda-architectes.com) 


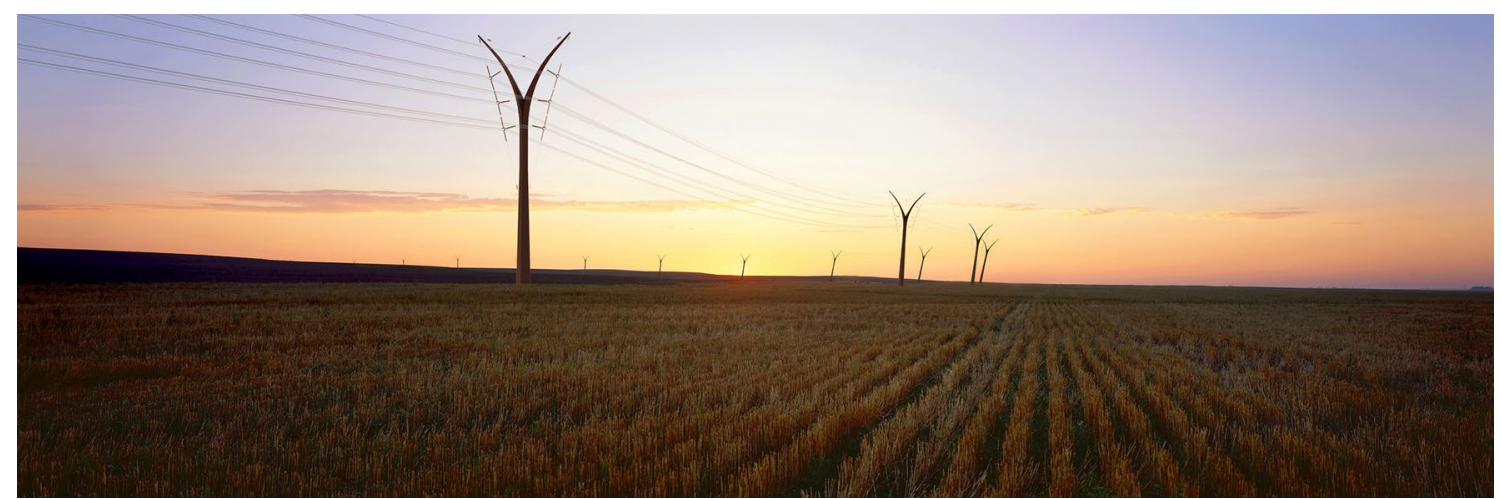

Fig. 28 Germogli pylon. HDA: Pylon Designer. Client: Terna. Competition Team: Hda, Rosenthal. Contractor:Tecnopali. Hda Team: Maria Angela Corsi (Competition Project Leader), Carla Zaccheddu, Francesco Cingolani, Pier Luigi Bucci, Gaëtan Kohler. Date: 2009-2013 (from http://www.hda-paris .com)

\section{Conclusions}

Towards a meta-interpretation of energy systems' image Today, it appears increasingly evident that the apparent conflict ES-landscape is completely outdated. The open question is rather how an ES can play a role in perception, planning and landscape management. One approach to face profitably in this matter comes from disciplines that deal with environmental and perceptual psychology.

Since the 90s, studies (Garcia-Martin et al. 2018; VallesPlanells et al. 2014; Mainardi Peron and Falchero 1994) on the perceptual dimension of landscape and human systems have identified four dimensions of perception: cognitive (related to thought, organization and information), affective (linked to emotions and personal feelings), interpretative (related to the extraction of meaning and the creation of idea associations) and evaluative (linked to values and preferences). According to these studies a mental map can be identified (that is the overall picture each person has made for a landscape and/or a city) which is necessarily partial (unable to understand the whole), simplified (because it omits a lot of information), idiosyncratic (every observer is unique) and distorted (based on distances and subjective directions).

Certainly, Lynch's studies (1960) provide an interpretation method, which can be used for the interpretive reading of the ES in relation to the landscape, although originally meant for other purposes: Lynch's analysis, in fact, still seems to find its utility and contemporaneity with regards to these thoughts. Its initial task was to define the interpretation categories of the city, but it is also a valuable tool to find out original interpretations and proposals concerning the relationship between ESs and their environment. Indeed, the various categories established in the previous discussion branch out into several other categories and sub-categories reflecting Lynch's work and carrying out expectations and goals.
The first of these categories is the path, which can be defined as a continuous system of elements and connection points, e.g. photovoltaic guardrails, kinetic energy recovery systems on roads and railways, etc. An ES becoming part of an explicit path itself clearly shows how energy and the related technology must follow man in his travels: photovoltaic guardrails are emblematic of the ability to use a still required support (the physical barrier of the motorway) in a multifunctional and economically advantageous way.

The second of such categories is the margin, which can be defined as a non-viable linear border, a linear interruption of continuity, a barrier, impenetrable and disruptive, an insulation. Wind turbines on ridges are a clear example of this concept: by their inherent characteristics they work very well in high and isolated places, towering over valleys and gullies, and thus ideally installable on mountain ridges and hills. However, this greatly amplifies the role of separation that a ridge already has: the compact row of wind turbines is perceived (even on plains) as a solid barrier rather than an isolated set of objects. Moreover, their movement instils an unjustified feeling of danger, especially into the flying fauna. They are still perceived as a separating wall and therefore identified as hostile elements which limit physical freedom of movement and of gazing beyond them.

The third category is represented by the concept of neighborhood, which is for Lynch a homogeneous urban area that, due to some general features, is perceived as a unit. The so-called eco-districts are a clear example of it. For instance, Vauban district in Freiburg (DE) was among the first "sustainable" bottom-up neighborhoods, required by the inhabitants themselves in order to organize a coordinated and energetically independent portion of the city, with high levels of energy efficiency and maximum use of renewable energy. Here the idea of ES is 
placed to the level of the neighborhood: the entire project is designed as a single ES, where the residences with their own solar greenhouses, parking garage with photovoltaic roof, central district heating and wind turbines contribute to the welfare of the inhabitants and to sustainability, both energetic and in terms of the entire intervention.

The node is the fourth reading category: it is a strategic focus, understood as the conjunction of courses or concentrations of certain features. Roundabouts are the fundamental nodes around which each driver is forced to rotate: sometimes they can be an opportunity for structuring an ES able to achieve more than a simple roundabout, a real focal point giving rise to a specific recognizability and highly distinguishable from all the other anonymous, cemented or weed-infested roundabouts.

Reference is the fifth concept borrowed from Lynch's analysis: it is a specific indication of external variable scale and recognizable and recognized ES belonging to a given place are inside this category. Strolling along the undifferentiated industrial and artisanal Lombard suburbs, sooner or later one would come across an element that undoubtedly suggests the arrival in Brescia: that is A2A waste-to-energy incinerator, which provides heat and electricity to a large part of city. The design of the building envelop was very nice and a particular attention was given to the chimney, seeking the intervention of Jorrit Tornquist, painter and expert in color and light. The intent was to disguise the chimney as much as possible through degrading and iridescent shades of blue and grey, quite similar to the color of the sky in Lombardy. While not exactly camouflaged, the resulting object seems highly recognizable and fluidly communicate with the landscape of the suburbs, valuing on a perceptual level also the adjoining highway infrastructure. This is an emblematic case of how an ES is able to transform a space (indefinite highway) in a place (the highway near Brescia).

The sixth key concept is the series, defined as a set of separate objects earning a rhythm over time. The most explanatory example is a row of power lines, always perceived as isolated, aligned elements characterized by a scanning rhythm which causes the idea of perceptual "series."

Two particularly enlightening categories-margin and series-represent a very clear example of how this categorization can be used in a profitable way. These two categories suggest why power lines (which are seen as series because they are composed by separate and distant objects-cables are invisible) are considered to produce a much lower impact than wind turbine blades, often placed next to each other on ridges, as they constitute an unbroken continuity (the rotors protrude significantly above the support pole and are quite close to each other) and mark a boundary, a margin, cutting off the landscape and the continuity of perception. This makes them (wind turbines) almost always unpopular and not accepted.

A simple but very significant example of ES planning (maybe not so consciously) driven by this method is Terna's International Contest ${ }^{8}$ on sustainable electric pylons. Power lines are usually considered only series and are usually rejected in "natural" context, but the main goal of the contest was to transform them into references, and thus into something appreciated and well accepted. Indeed, the new pylons look like landmarks: they have been designed to be exhibited and integrated into the landscape, as Fig. 28.

The study of the proposed method is not meant to be objective or aseptic: each category can be a meta-planning orientation for the ES, guiding the choices also during the planning phase and pointing out the influence margins in addition to the expected performance. The identified categories can lead stakeholders in their planning choices and help resolving the conflicts which arise when an innovation is proposed in the field of energy conversion and production.

It is necessary, also through energy management, to restore the ability to make project changes, thus recovering the conscious ability to actively create landscape.

\section{Abbreviations \\ ES: energy system(s); RES: renewable energy system(s).}

\section{Authors' contribution}

This manuscript was entirely elaborated and written by both the authors. Both authors read and approved the final manuscript.

\section{Acknowledgements}

Not applicable.

Competing interests

The authors declare that they have no competing interests.

Availability of data and materials

All data generated or analysed during this study are included in this published article.

Funding

No funding was received.

\section{Publisher's Note}

Springer Nature remains neutral with regard to jurisdictional claims in published maps and institutional affiliations.

Received: 30 July 2018 Accepted: 26 October 2018

Published online: 02 November 2018

\footnotetext{
${ }^{8}$ http://download.terna.it/terna/0000/0018/70.pdf.
} 


\section{References}

Blaschke T, Biberacher M, Gadocha S, Schardinger I (2013) Energy landscapes: meeting energy demands and human aspirations. Biomass and Bioenergy, vol 55. Elsevier, New York, pp 3-16

Dardel É, Buttimer A, Copeta C (eds) (1986) L'uomo e la terra: natura della realtà geografica. Unicopli, Milano

DeWall RM, Stremke S (2014) Energy transition: missed opportunities and emerging challenges for landscape planning ad designing. Sustainability 6:4386-4415. https://doi.org/10.3390/su6074386

Garcia-Martin M, Plieninger T, Bieling C (2018) Dimensions of landscape stewardship across Europe: landscape values, place attachment, awareness, and personal responsibility. Sustainability 10(1):263

Ginelli E, Daglio L (2014a) Relationship between energy systems and landscape. Guidelines and tools for design and management. In: TECHNE, vol 8. ISSN: 2239-0243

Ginelli E, Daglio L (2014b). Energyscapes: developing a multiscalar systemic approach to assess the environmental, social and economic impact of renewable energy systems on landscape. In: Proceedings of the 2 nd ICAUD international conference in architecture and urban design Epoka University, Tirana, Albania, pp 152/1-152/8

Ginelli E, Daglio L (2015) A multidimensional analysis to manage the relation between energy and landscape. In: The fifteenth international conference on civil, structural and environmental engineering computing, Prague. Available via CIVIL-COMP PRESS. http://civil-comp.com/conf/conf2015/ cc2015.htm. Accessed 1 Sept 2015

Golledge RG, Stimson R (1987) Analytical behavioural geography. Croom Helm, London

Harris LR, Watts ME, Nell E et al (2014) Using multivariate statistics to explore trade-offs among spatial planning scenarios. J Appl Ecol 51:1504-1514

Howard DC et al (2013) Energyscapes: linking the energy system and ecosystem services in real landscapes. Biomass and Bioenergy, vol 55. Elsevier, New York, pp 17-26

Jorgensen SE, Costanza R, Xu FL (2008) Handbook of ecological indicators for assessment of ecosystem health. CRC Press-Taylor\&Francis Group, Boca Raton

Llausas A, Nogue J (2012) Indicators of landscape fragmentation: the case for combining ecological indices and the perceptive approach. Ecol Ind 15(1):85-91

Lynch K (1960) The image of the city. MIT Press, Cambridge

Mainardi Peron E, Falchero S (1994) Ambiente e conoscenza. Aspetti cognitivi della psicologia ambientale, Carocci
Matsuoka RH, Kaplan R (2008) People needs in the urban landscape: analysis of landscape and urban planning contributions. Landsc Urban Planning 84(1):7-19

Meschiari M (2008) Sistemi selvaggi, antropologia del paesaggio scritto. Sellerio, Palermo

Nadaï A, Van der Horst D (2010) Introduction: landscapes of energies. Landsc Res 35(2):143-155

Nijkamp P (2008) XXQ factors for sustainable urban development: a system economics view. Romanian J Regional Sci 2(1):1-34

Paolillo PL, Rossati M, Rudini MA (2013) Multivariate applications in the evaluation of the discipline of agriculture: extra-urban spaces and the resistivity index. Geo-informatics in resource management and sustainable ecosystem, vol 399. Springer, Heidelberg, pp 53-65

Pasqualetti MJ (2011) Social barriers to renewable energy landscapes. Geographical review, vol 101. American Geographical Society, New York, pp $201-223$

Potthoff K (2007) Landscape change as an interface for different approaches in landscape research. Erdkunde 61(1):54-71

Raymond CM, Kytta M, Stedman R (2017) Sense of place, fast and slow: the potential contributions of affordance theory to sense of place. Front Psychol 8:1674

Ritter J, Venturi Ferriolo M (eds) (1994) Paesaggio, uomo e natura nell'età moderna. Guerini e Associati, Milano

Sereni E (1961) Storia del paesaggio agrario italiano. Editori Laterza, Bari

Stremke S, Van den Dobbelsteen A (2013) Sustainable energy landscape. CRC Press, New York

Theodor J, Stewart S, French JR (2013) Integrating multicriteria decision analysis and scenario planning. Omega, vol 41. Elsevier, New York, pp 679-688

Valles-Planells M, Galiana F, Van Eetvelde V (2014) A classification of landscape services to support local landscape planning. Ecol Soc 19(1):44

Van Der Horst D, Vermeylen S (2011) Local rights to landscape in the global moral economy of carbon. Landsc Res 36(4):455-470

Venturi Ferriolo M (2002) Etiche del paesaggio. II progetto del mondo umano, Editori Riuniti

Zagari F (2006) Questo è paesaggio. 48 definizioni. Gruppo Mancosu Editore, Roma

\section{Submit your manuscript to a SpringerOpen ${ }^{\odot}$ journal and benefit from:}

- Convenient online submission

- Rigorous peer review

- Open access: articles freely available online

- High visibility within the field

Retaining the copyright to your article

Submit your next manuscript at springeropen.com 